\title{
Klasifikasi Jenis Jamur Konsumsi Berbasis Android Menggunakan Metode K-Nearset Neighbors (KNN)
}

\author{
Darsilowati ${ }^{1}$, Aditya Akbar Riadi², Evanita ${ }^{3}$ \\ 1 Universitas Muria Kudus / Teknik Informatika \\ 2 Universitas Muria Kudus / Teknik Informatika \\ 3 Universitas Muria Kudus / Teknik Informatika
}

\begin{abstract}
The use of android-based applications today is not something new. Every day there are always new android applications, each application has its own function. Starting from entertainment, education and so on. Similarly, this edible mushroom grouping application aims to make it easier for the public to find out whether the mushrooms obtained are edible or not. This application is designed to minimize the incidence of mushroom poisoning among the public due to the lack of information about these mushrooms. This application will also make it easier for people to easily find the information they need. Only by using a smartphone can they get the information they need. The use of android also makes it easier for anyone who wants to use it, because the android system is widely known and used by the public. So that can make it easier. In designing the android program using a K-Nearest Neighbor $(K-N N)$ algorithm method, which is a method that classifies objects based on the learning data that is closest to the object. The learning data is drawn into a multidimensional space with each dimension representing each feature of the data.
\end{abstract}

Keywords: Mushroom, Android System, K-Nearest Neighbor (K-NN)

corresponding email : 201751062@umk.ac.id

This is an open access article under the $\underline{C C B Y}$ license

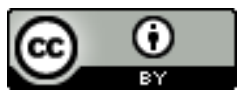

\section{INTRODUCTION}

Seiring dengan perkembangan teknologi yang semakin maju dan berkembang pesat kemunculan berbagai apllikasi pada android juga berbanding lurus dengan perkembangan teknologi. Semakin hari perkembangan aplikasi android semakin maju. Banyak aplikasi yang sangat berguna untuk kehidupan. Mulai dari aplikasi untuk mempermudah kegiatan belajar, aktivitas harian, pencarian dan banyak lagi. Dibidang pencarian data banyak aplikasi yang menawarkan berbagai fitur dan kegunaan yang sangat membantu masyarakat untuk mencari informasi yang ingin diketahui. Dari situlah dirancang sebuah program yang bertujuan untuk membantu msayarakat dalam mencari informasi yang diperlukan. Program tersebut adalah sebuah aplikasi pengelompokan jamur yang bisa dimakan berdasarkan bentuk dan warna menggunakan metode klasifikasi berbasis android.

Pada saat ini dikalangan masyarakat sendiri masih sering dijumpai beberapa jenis jamur yang tidak diketahui dari jenis apa, apakah bisa dimakan ataukah tidak. Sehingga sering membuat masyarakat kebingungan dan akhirnya hanya menggunakan insting mereka. Tak ayal sering terjadi kasus keracunan yang diakibatkan oleh konsumsi jamur yang beracun. Pengembangan aplikasi ini diharapkan dapat membantu masyarakat dalam mencari informasi jamur yang hendak mereka makan. Sehingga tidak ada lagi kasus keracunan karena jamur yang dikonsumsi tanpa tau apakah jamur tersebut dapat dimakan atau tidak. 
JAST : Journal of Applied Science and Technology

Volume. 1 Number. 2, July 2021

ISSN : 2775-4022

http://jurnal.unissula.ac.id/index.php/JAST

\section{LITERATURE REVIEW}

Ada beberapa penelitian sebelumnya yang membahas menenai klasifikasi jamur yang dapat dikonsumsi ada juga tentang klasifikasi objek lainnya yang dapat digunakan untuk bahan acuan penelitian selanjutnya. Hasil penelitian tersebut ditemukan dalam basis data jurnal online karena telah dipublikasikan yaitu antara lain :

1. Hasil penelitian Yuda Permadi dkk (2015) yang berjudul " aplikasi pengolahan citra untuk identifikasi kematangan mentimun berdasarkan tekstur kulit buah menggunakan metode ekstraksi ciri statistik ". Yaitu sebuah penelitian yang meguji tingkat kematangan dari sebuah mentimun berdasarkan kulitnya sehingga mempermudah bagi petani mentimun.

2. Hasil penelitian Sapriani Gustina dkk (2017) yang berjudul " sistem identifikasi jamur menggunakan metode ekstraksi ciri statistik orde 1 dan klasifikasi jarak ". Penelitian yang mengungkapan bagaimana menklasifikasi jamur dengan memanfaatkan ciri khas dari jamur tersebut dan juga menggunakan jarak yang ada untuk menentukan jenis jamur yang diinginkan.

3. Hasil penelitian Fitri Muwardi dan Abdul Fadlil (2017) yang berjudul " sistem pengenalan bunga berbasis pengolahan citra dan pengkalsifikasi jarak". Adalah sebuah penelitian untuk menentukan jenis bunga dengan menggunakan pengolahan citra dengan pemanfaatan jarak dan pengolahan warna.

4. Hasil penelitian Julian Fuad Fauzi dkk (2018) yang berjudul " implementasi metode RGB To HVS pada aplikasi pengenalan mata uang kerta berbasis android untuk tuna netra ". Penelitian yang mempermudah bagi orang - orang tuna netra untuk mengenali warna yang ada pada mata uang dengan perubahan warna.

5. Hasil penelitian Sarlita Hartiningtyas dkk (2018) yang berjudul “ klasifikasi jenis mangga berdasarkan bentuk buah dengan metode k-nearest neighbor berbasis android ". Yaitu sistem yang digunakan untuk menentukan jenis buah mangga berdasarkan bentuknya dengan menggunakan pengolahan citra.

\section{RESEARCH METHOD}

Metode penelitian adalah sebuah cara untuk mengetahui hasil dari sebuah permasalahan yang spesifik dengan cara mengumpulkan data atau informasi guna memecahkan permasalahan dan menguji hipotesis penelitian. Adapun metode yang digunakan penulis pada penelitian ini antara lain :

1. Metode Pengumpulan Data, pengumpulan data dilakukan untuk memperoleh imformasi yang dibutuhkan dalam mencapai tujuan penelitian. Adapun metode pengumpulan data tersebut antara lain:

a. Observasi

Penulis mendatangi objek yang diteliti secara langsung dengan tujuan untuk melakukan observasi dan melakukan pengamatan mengenai jenis jamur yang ada apakah termasuk jenis jamur yang aman dikonsumsi ataupun jenis jamur yang tidak dapat dikonsumsi.

b. Studi Pustaka

Studi pustaka dilakukan dengan cara mengumpulkan data dan informasi dari membaca dan mempelajari buku-buku, referensi serta situs-situs penyedia layanan yang berhubungan dengan program pengklasifikasian jenis jamur konsumsi berbasis android.

2. Pengembangan Program, Dalam pengembangan program diperlukan bahan, alat dan tahapan-tahapan yang akan dilalui untuk membuat program yang dirancang dapat berjalan. Tahapan-tahapan tersebut antara lain:

a. Bahan-bahan yang digunakan dalam penelitian ini adalah: Berbagai jenis jamur yang akan digunakan untuk dijadikan data oleh program yang telah dibuat.

b. Alat penelitian yang digunakan dalam penelitian ini adalah: Sebuah laptop, handphone yang akan digunakan untuk membuat program dan untuk menguji program tersebut.

c. Tahap-tahap pembangunan program meliputi: Tahap perencanaan, Tahap analisis, Tahap perancangan program, Uji coba kegiatan, Tahap implementasi. 


\section{Flowchart}

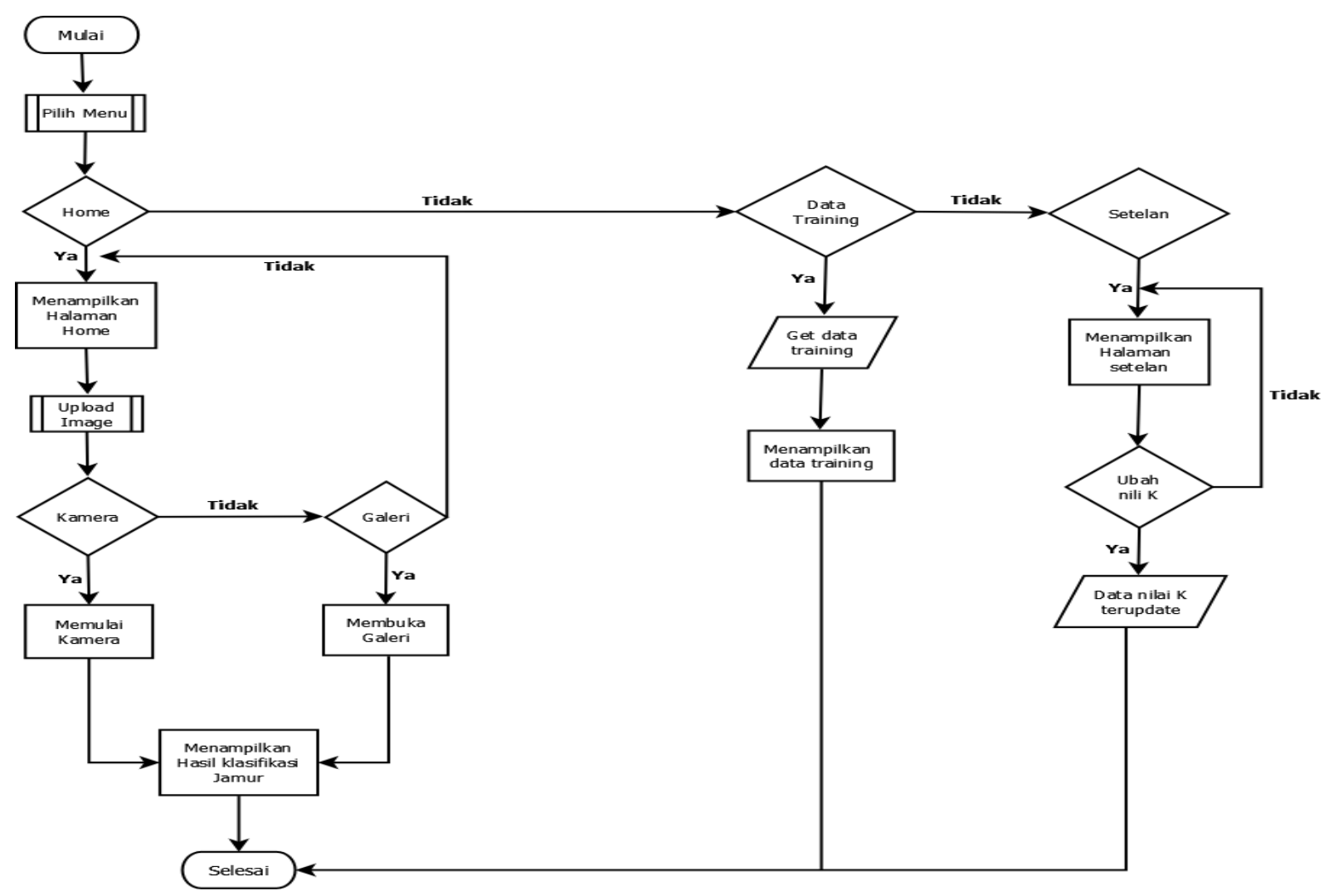

Figure 1

Adapun penjelasan dari rancangan flowchart diatas yaitu dimulai pada saat pertama kali membuka aplikasi akan diarahkan kehalaman utama dimana pada halaman utama terdapat tiga menu yang dapat dipilih. Tiga menu tersebut adalah menu Home, Data Training, dan Setelan. Pada menu Home, user diarahkan untuk mengupload gambar dari jamur yang ingin diketahui apakah termasuk jamur beracun atau tidak. User sendiri memiliki dua cara untuk mengupload gambar. Cara pertama adalah dengan memfoto langsung objek dengan kamera, atau memilih foto objek sebelumnya yang terdapat pada galeri.

Setelah memilih dan memasukkan kedalam sistem, maka sistem selanjutnya memproses data yang ada untuk menampilkan hasil yang telah didapat dari pengolahan data yang ada, dari hasil pengolahan data tersebut akan diketahui apakah jamur tersebut beracun atau tidak. Dimenu selanjutnya adalah menu Data Training, pada menu ini pengguna dapat melihat data training yang sudah ada pada program. Kemudian pada menu setelan yang mempunyai fungsi untuk memasukan nilai $\mathrm{K}$ yang ingin digunakan oleh pengguna.

\section{Data Flow Diagram}

DFD LEVEL 0

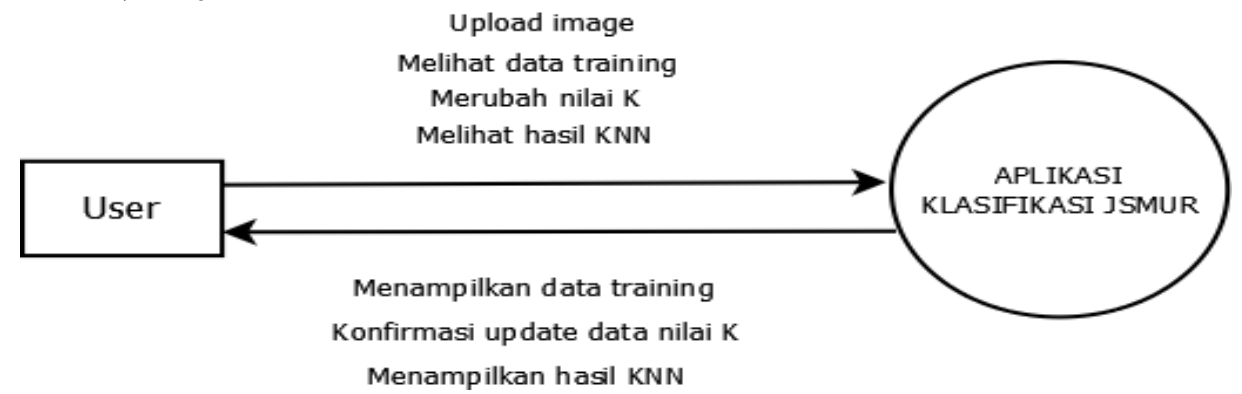

Figure 2 
JAST : Journal of Applied Science and Technology

Volume. 1 Number. 2, July 2021

ISSN : 2775-4022

http://jurnal.unissula.ac.id/index.php/JAST

Penjelasan dari DFD level 0 pada gambar diatas adalah, user memiliki empat perintah masukan (input) pada sistem. Empat perintah tersebut adalah upload image (gambar), melihat data tarining, merubah nilai $\mathrm{K}$, dan yang terakhir adalah melihat hasil KNN. Dari perintah yang diperoleh dari user maka sistem akan mengeluarkan (output) yang berupa menampilkan data training, konfirmasi update data nilai $\mathrm{K}$, dan yang terakhir adalah menampilkan hasil dari KNN.

\section{DFD LEVEL 1}

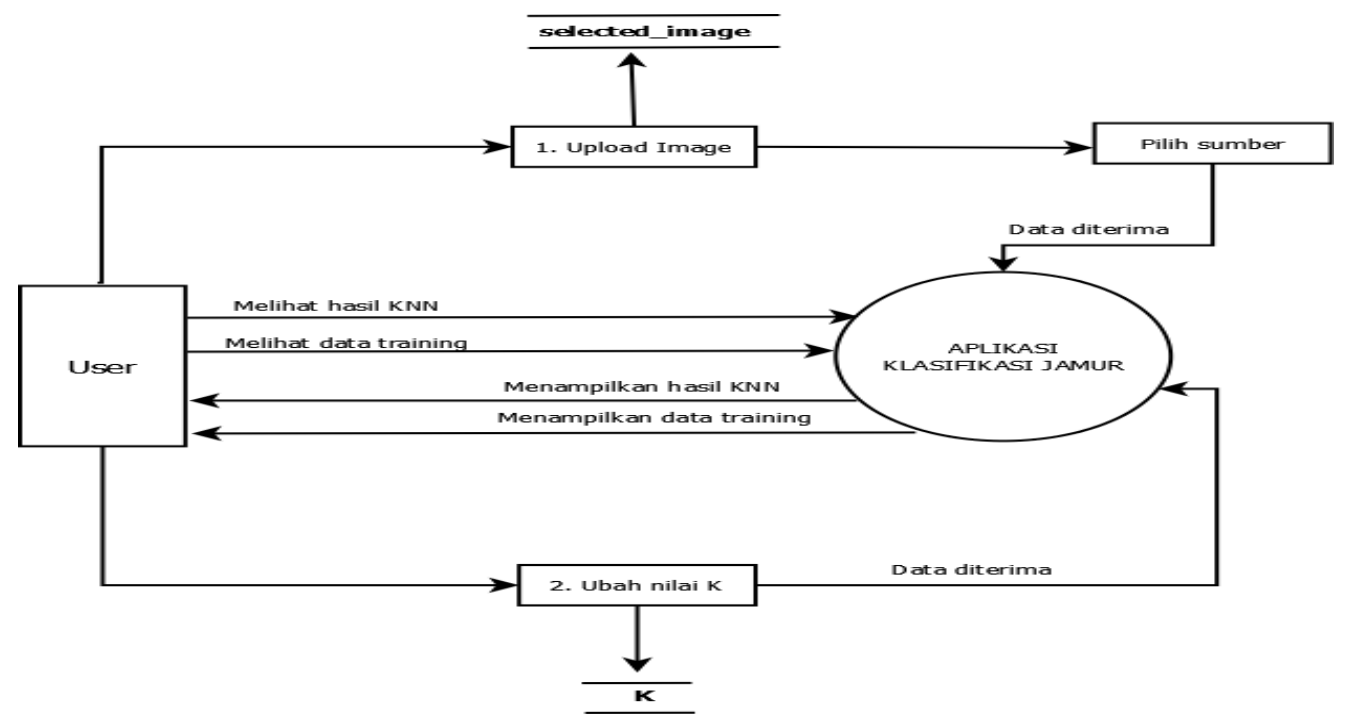

Figure 3

Pada DFD level 1 ini dapat dilihat bahwa user dapat melihat hasil KNN dengan cara user dapat mengupload sebuah gambar yang nanti akan digunakan untuk perhitungan KNN (input), saat akan mengupload gambar maka user dapat memilih sumber gambar tersebut berada. Setelah user selesai memilih gambar yang diinginkan maka data tersebut akan diterima oleh sistem kemudian data tersebut akan diolah dengan menggunakan metode KNN. Setelah diolah dengan menggunakan KNN, sistem akan menampilkan hasil dari pengolahan tersebut kepada user (output).

User juga dapat melakukan inputan berupa untuk mengubah nilai dari $\mathrm{K}$, dimana saat user memginputkan nilai dari $\mathrm{K}$ tersebut maka data tersebut akan masuk kedalam database dengan nama tabel $\mathrm{K}$, kemudian sistem akan menerima data tersebut kemudian menyampaikan kembali kepada user bahwa nilai dari $\mathrm{K}$ telah berhasil diubah atau ditambahkan. User juga dapat membuat perintah untuk melihatkan Data Training yang telah ada pada sistem dan sistem akan menampilkan Data Training tersebut.

DFD LEVEL 2

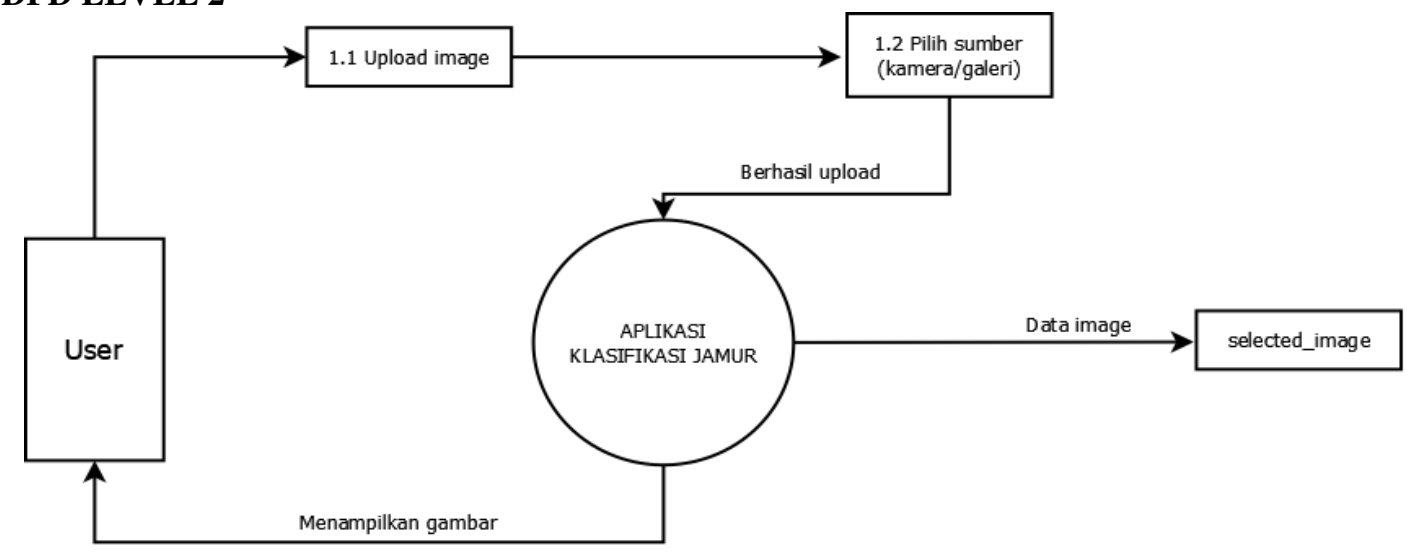

Figure 4 
JAST : Journal of Applied Science and Technology

Volume. 1 Number. 2, July 2021

ISSN : 2775-4022

http://jurnal.unissula.ac.id/index.php/JAST

Pada DFD level 2 menjelaskan bagaimana mana cara kerja dari sistem aplikasi klasifikasi jamur. Yaitu dengan cara user pertama kali akan mengupload sebuah gambar yang dipilih dari salah satu sumber yang ada. User dapat memilih antara menggunakan kamera atau memilih dari galeri yang ada. Kemudian setelah user memilih gambar yang akan diolah maka sistem akan menerima data tersebut. Kemudian sistem akan mencari data yang berkaitan dengan gambar yang diupload oleh user didatabase yang ada. Tahap selanjutnya sistem akan menampilkan gambar tersebut kepada user.

\section{DFD LEVEL 3}

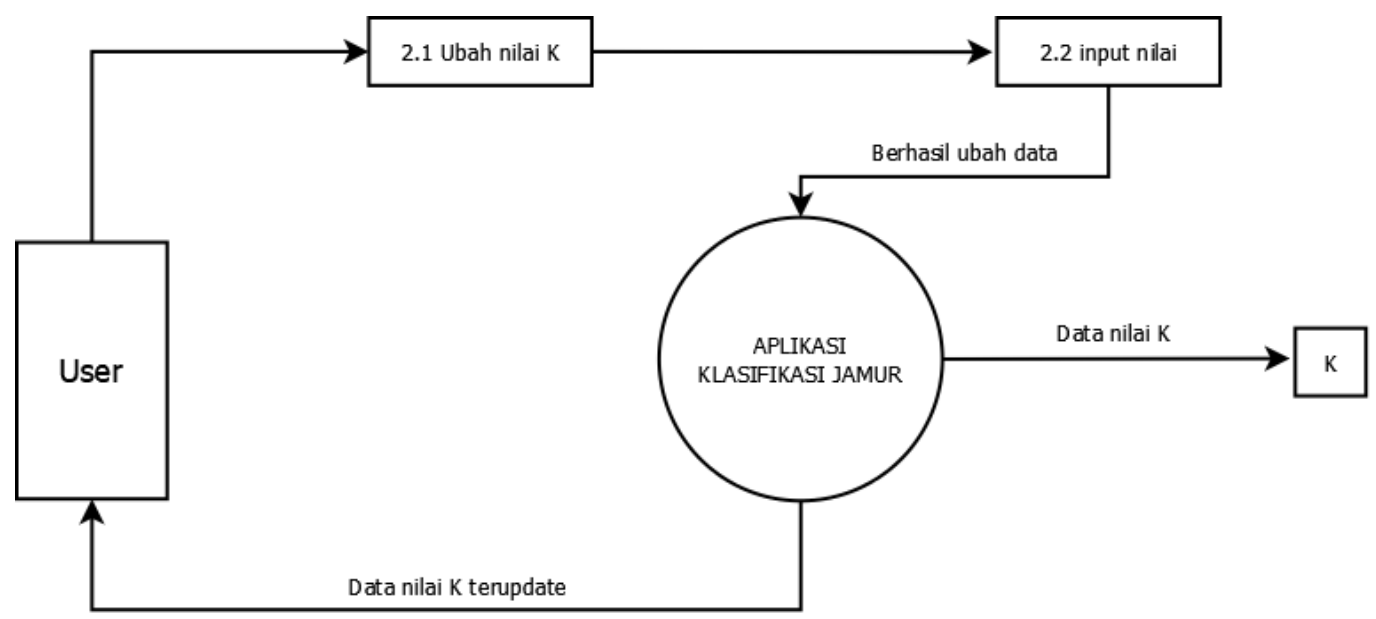

Figure 5

DFD level 3 menjelaskan cara kerja dari perubahan nilai K yang dapat dilakukan olaeh user. Tahap pertama yaitu user memilih pilihan untuk mengubah nilai dari K. Kemudian user menginputkan nilai dari K. Hasil dari inputan user inilah kemudian akan diterima oleh user sehingga data berhasil diubah. Sistem selanjutnya akan menyimpan data tersebut ke database yang ada. Sistem kemudian memberikan informasi bahwa nilai $\mathrm{K}$ sudah terupdate.

\section{RESULT AND ANALYSIST}

a) Tampilan Masuk

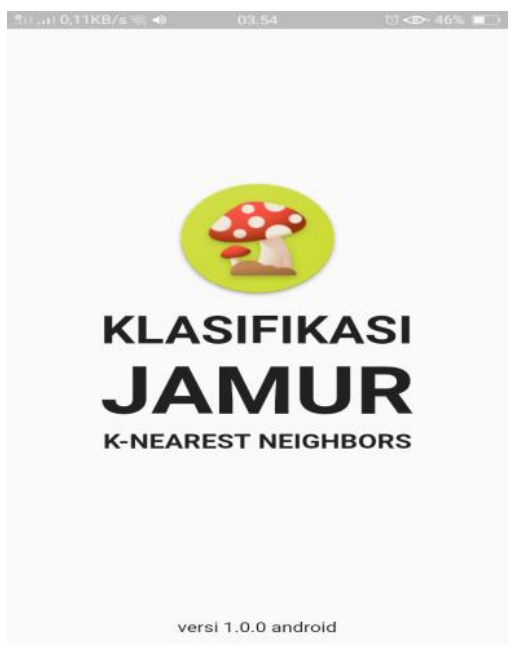

Figure 6

Pada tampilan awal masuk hanya ada nama dari aplikasi dan versi android dari aplikasi. 
JAST : Journal of Applied Science and Technology

Volume. 1 Number. 2, July 2021

ISSN : 2775-4022

http://jurnal.unissula.ac.id/index.php/JAST

b) Tampilan Home

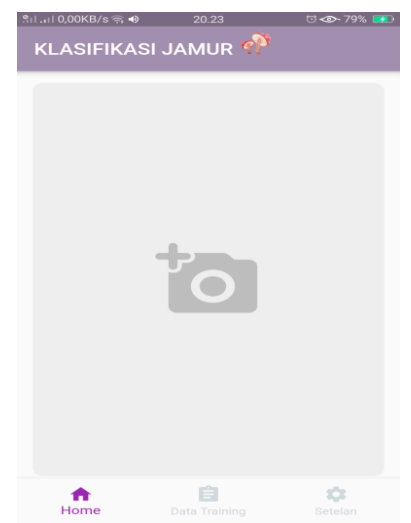

Figure 7

Pada tampilan awal ini user akan melihat tiga buah pilihan menu yaitu Home itu sendiri, Data Training, dan Setelan. Pada tampilan Home inilah user dapat menjalankan atau mencoba untuk mengetahui apakah jamur tersebut beracun atau tidak.

c) Tampilan Halaman Data Training

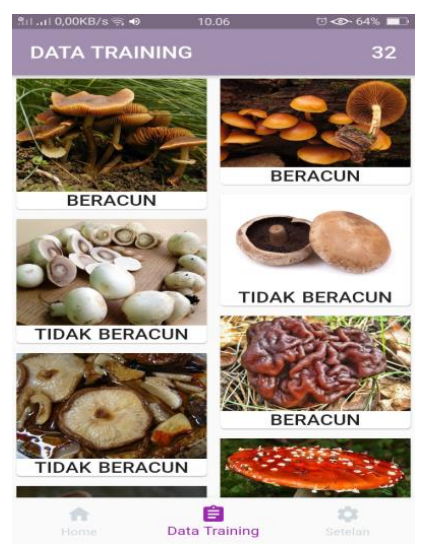

Figure 8

Pada halaman Data Training terdapat sekumpulan gambar dari berbagai jenis jamur yang sudah memiliki keterangan apakah jamur tersebut beracun atau tidak beracun. Pada halaman ini user tidak dapat merubah Data Training yang ada. Data Training inilah yang menjadi acuan untuk mengklasifikasikan jamur yang ada dengan menggunakan metode K-Nearest Neighbor.

\section{d) Tampilan Halaman Setelan}

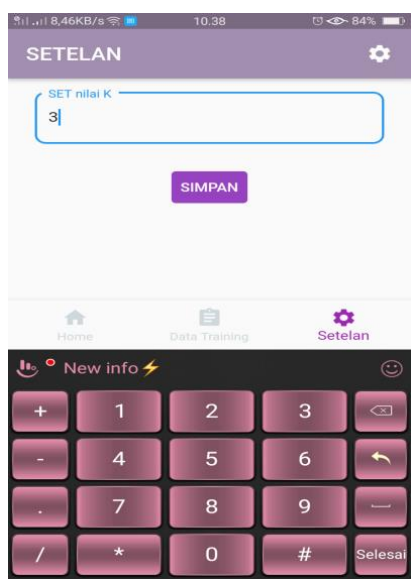

Figure 9 
JAST : Journal of Applied Science and Technology

Volume. 1 Number. 2, July 2021

ISSN : 2775-4022

http://jurnal.unissula.ac.id/index.php/JAST

Pada halaman ini mempunyai fungsi untuk menyetel atau menentukan jumlah $\mathrm{K}$ pada aplikasi yang nanti akan digunakan untuk menjalankan perhitungan yang ada dengan menggunakan metode KNN. Berikut adalah tampilan pada halaman Setelan.

\section{CONCLUSION}

Dengan adanya aplikasi ini mengklasifikasikan berbagai jenis jamur yang awam untuk dijumpai akan semakin mudah karena dapat dilakukan dengan menggunakan handphone dimana semua orang pada saat ini memilikinya. Sehingga dapat memberikan wawasan baru bagi masyarakat tentang berbagai jenis jamur yang dapat dikonsumsi atau tidak.

\section{REFERENCES}

[1] Ed $\quad$ Burnette., 2009, Hello Android 2 2nd USA.

[2] Fauzi, J. F., Tolle, H., Dewi, R. K. (2018). Implementasi Metode RGB To HVS Pada Aplikasi Pengenalan Mata Uang Kertas Berbasis Android Untuk Tuna Netra. Jurnal Pengembangan Teknologi Informasi Dan Ilmu Komputer, 2(6), 2319-2325.

[3] Gustina, S., Fadlil, A., Umar, R. (2017). Sistem Identifikasi Jamur Menggunakan Matode Ekstraksi Ciri Statistik Orde 1 Dan Klasifikasi Jarak. Techno.com, 16(4), 378-386.

[4] Hartiningtyas, S., Ruslianto, I., Hidayati, R. (2018). Klasifikasi Jenis Mangga Berdasarkan Bentuk Buah Dengan Metode K-Nearest Neighbor Berbasis Android. Jurnal Coding, 6(1), 12-23.

[5] Informatikalogi. (2020, November 28). Algoritma K-Nearest Neighbor (K-NN). Dipetik April 20, 2021, dari informatikalogi.com: https://informatikalogi.com/algoritma-k-nn-k-nearest-neighbor/

[6] Muwardi, F., \& Fadlil, A. (2017). Sistem Pengenalan Bunga Berbasis Pengolahan Citra Dan Pengklasifikasi Jarak. Jurnal Ilmu Teknik Elektro Komputer Dan Informatika (JITEKI), 3(2).

[7] Oktanisa, I., \& Supianto, A. A. (2018). Perbandingan Teknik Klasifikasi Dalam Data Mining Untuk BAnk Direct Marketing. Jurnal Teknologi Informasi Dan Ilmu Komputer (JTIIK), 5(5), 567-576.

[8] Permadi, Y., \& Murinto. (2015). Aplikasi Pengolahan Citra Untuk Identifikasi Kematangan Mentimun Berdasarkan Tekstur Kulit Buah Menggunakan Metode Ekstraksi Ciri Statistik. Jurnal Informatika, 9(1).

[9] Saryani, I. G. A. D. (2017). Perancangan Aplikasi Notifikasi Pembuatan Baglog Jamur Tiram. Techno.com, 16(1), 96-105. 